\title{
Carbon Exchange Rate and Accumulation in Limbs of Fruiting and Nonfruiting Apple Trees
}

\author{
Ido Schechter ${ }^{1}$ and J.T.A. Proctor \\ Department of Horticultural Science, University of Guelph, Guelph, Ontario N1G 2W1, Canada \\ D.C. Elfving ${ }^{2}$ \\ Horticultural Research Institute of Ontario, Vineland Station, Ontario LOR 2E0, Canada
}

Additional index words. dry-weight increment, fruiting and nonfruiting spur leaves, Malus domestica, root, shoot leaves

\begin{abstract}
Mature 'Sturdeespur Delicious' apple (Malus domestica Borkh.) trees on MM.106 rootstocks were hand-deblossomed or hand-pollinated in 1989 and 1990. Two representative limbs were chosen at bloom on each tree in 1989, one of which was girdled (G) while the other served as a control. One representative limb was selected at bloom in 1990. Three leaf types were studied: shoot (SH) leaves, leaves on nonfruiting (NF) spurs (S - F), and leaves on fruiting (F) spurs $(S+F)$. The presence of fruit did not affect $C$ exchange rate (CER). Girdling fruiting limbs reduced CER by $\approx 10 \%$. Girdling NF limbs resulted in starch accumulation in the leaves and low CER. SH leaves had the highest CER per unit leaf area, while $S+F$ leaves had the lowest. Total seasonal dry weight (DW) accumulated in leaves, fruit, and wood, normalized per square centimeter limb cross-sectional area (LCSA), was higher in F trees. Roots were longer and DW of roots extracted from soil core samples was higher in NF trees. NF trees had significantly more vegetative growth in new shoots and dry-matter increment in wood than $F$ trees.
\end{abstract}

Yield at a given net $\mathrm{C}$ exchange rate (CER) depends on the photoassimilates available for export (source regulation) and on the capacity of consuming organs to import carbohydrates (sink regulation) (Daie, 1985). Flore and Lakso (1989) and Forshey and Elfving (1989) support the hypothesis that fruit increase CER in apple trees. This phenomenon has been reported for detached limbs, spurs, or shoots (Fujii and Kennedy, 1985; Hansen, 1970), for intact leaves (Ghosh, 1973) and for whole, potted trees (Avery et al. 1979; Monselise and Lenz, 1980). The reported increases in CER due to fruiting ranged from $0 \%$ to $400 \%$, but evidence for this response has not been consistent (Gifford and Evans, 1981). Proctor et al. (1976) did not detect a decrease in CER after fruit removal, and no differences were observed in CER between fruiting $(\mathrm{F})$ and nonfruiting (NF) spurs on $\mathrm{F}$ trees (Ferree and Palmer, 1982; Rom and Ferree, 1986), and between F and NF tree quadrants or branches on the same trees (Palmer et al., 1991). According to Flore and Lakso (1989), studies of mature, field-grown trees are needed to clarify $\mathrm{F}$ effects on CER in intact trees.

Total above-ground dry-matter production in $\mathrm{F}$ trees was higher than in NF trees, despite the suppression of vegetative growth induced by $\mathrm{F}$ (Chandler and Heinicke, 1926). F suppresses the growth of other plant parts, but increases dry-matter production per unit leaf area (Avery, 1969, 1975; Maggs, 1963; Priestley, 1970a; Verheij, 1972).

F reduced total tree leaf area and dry weight (DW) (Avery, 1969; Proctor et al., 1976; Verheij, 1972), shoot growth (Avery, 1969; Barlow, 1964, 1966; Maggs, 1963), trunk growth (Barlow, 1964; Erf and Proctor, 1987), and stored carbohydrate levels in woody tissues (Priestley, 1970a, 1970b), whereas deblossoming and defruiting increased vegetative growth (Erf and Proctor, 1987;

\footnotetext{
Received for publication 6 Apr. 1992. Accepted for publication 29 June 1993. This research was supported by operating grant no. A6697 of the Natural Sciences and Engineering Research Council of Canada held by J.T.A.P. We gratefully acknowledge the assistance of Dean Louttit and Wayne Pierce. The cost of publishing this paper was defrayed in part by the payment of page charges. Under postal regulations, this paper therefore must be hereby marked advertisement solely to indicate this fact.

${ }^{1}$ Present address: 185 Nahal Meshushim St., Makabim D.N., Modiim 71908, Israel. ${ }^{2}$ Present address: Tree Fruit Research and Extension Center, Washington State Univ., 1100 N. Western Ave., Wenatchee, WA 98801.
}

Forshey and Marmo, 1985). Root growth has been reduced (Avery, 1969; Hansen, 1971; Head, 1969) or even stopped (Avery, 1970) by $\mathrm{F}$. The largest proportional reductions in growth due to $\mathrm{F}$ take place in the root system (Maggs, 1963).

Secondary thickening of woody tissues occurs primarily after shoot growth ceases (Forshey et al., 1983). Barlow (1975) showed that the major effect of crop load on secondary thickening occurred in the season of cropping, with Maggs (1963) reporting a 50\% reduction in seasonal dry-matter accumulation in the trunks of $\mathrm{F}$ trees.

Cropping has only a minor influence on the apportionment of the vegetative increment within the tree (Forshey and Elfving, 1989). The fruit, positioned near the sources of assimilate supply, seem to act as independent sinks, withdrawing part of the available assimilates, while the remaining assimilates are then distributed among the vegetative parts of the tree in essentially the same proportions as in noncropping trees (Forshey and Elfving, 1989). Understanding seasonal $\mathrm{C}$ assimilation and partitioning will help develop strategies for manipulating DW allocation, thereby influencing yield.

The objective of this investigation was to determine if the presence of fruit on limbs of mature, field-grown apple trees influences CER and dry-matter accumulation.

\section{Materials and Methods}

Mature 'Sturdeespur Delicious'/MM.106 trees planted in 1977 at the Horticultural Experiment Station, Simcoe, Ontario, were spaced at $3 \times 5 \mathrm{~m}$ (667 trees/ha) in north-south-oriented rows. The average trunk cross-sectional area in spring 1989 was $85 \mathrm{~cm}^{2}$, and canopy width and height averaged 3 and $3.2 \mathrm{~m}$, respectively. The orchard soil was a moderately well-drained Walsher sandy loam composed of 40 to $100 \mathrm{~cm}$ of sandy-loamy material over glaciolacustrine clay. The central-leader-trained trees had a consistent annual cropping cycle (average for $1985-88,80 \mathrm{~kg} / \mathrm{tree}$ ). Dormant pruning, fertilizers, pesticides and herbicides were applied as required according to standard commercial practices. Sprinkler irrigation was used whenever tensiometer readings 30 and $45 \mathrm{~cm}$ deep in the orchard reached at least $-40 \mathrm{kPa}$.

In Spring 1989, a trial was established with five completely 
randomized blocks, each containing two adjacent trees similar in size, cropping history, and bloom density. One tree from each block was hand-deblossomed and the other hand-pollinated daily from the time $20 \%$ of blossoms had opened until $50 \%$ of the petals had fallen. Hand-pollinated trees set a heavy crop, while the deblossomed trees had no fruit. Two limbs of $\approx 15 \mathrm{~cm}$ in circumference at a height of 1.0 to $2.0 \mathrm{~m}$ were chosen at bloom on each tree as described by Forshey and Elfving (1979). One limb of each pair was a control, while the other was girdled (G) (28 June) after June drop $(\approx 22$ June). Full bloom occurred on 25 May. A 1.5cm-wide strip of phloem, cambial tissue, and connected bark was removed, and the exposed ring was covered with lanolin. The girdle was monitored periodically for cambial growth and was scraped when necessary to prevent phloem reconnection. Terminal bud formation took place in July each year; $F$ trees formed terminal buds $\approx 2$ weeks ahead of NF trees.

Leaves were segregated into three categories for study: shoot (SH) leaves, leaves on NF spurs $(\mathrm{S}-\mathrm{F})$, and leaves on F spurs ( $\mathrm{S}$ $+F)$. The climatic conditions and the spur-type strain used resulted in very few bourse shoots (zero to three per tree); leaves were not sampled from spurs with bourse shoots.

Heavy cropping on the $\mathrm{F}$ trees in 1989 reduced their return bloom in 1990. However, supplemental hand-pollination of the 1990 bloom on two of the trees that cropped in 1989 resulted in their setting a moderate crop. These two F trees were compared during the 1990 season with the other tree in the respective block, which was hand-deblossomed for the second consecutive year. A new, nongirdled (NG) limb was selected from each tree at bloom for study in 1990 (Forshey and Elfving, 1979).

Gas exchange. CER, stomatal conductance (SC), and internal $\mathrm{CO}_{2}$ concentration $\left(\mathrm{C}_{\mathrm{i}}\right)$ were measured using a portable photosynthesis system (model LI-6200; LI-COR, Lincoln, Neb.) equipped with a 250-ml leaf chamber (total system gas volume $=390 \mathrm{ml}$ ). A healthy, fully expanded, well-exposed leaf, 1.0 to $2.0 \mathrm{~m}$ high, was inserted into the leaf chamber, and three consecutive measurements of $10 \mu \mathrm{mol} \cdot \mathrm{mol}^{-1} \mathrm{CO}_{2}$ drawdown were taken on the same leaf. The mean of the three drawdown measurements was used as a plot value in the statistical analyses. SH leaves used for CER measurements were located about midway on terminal and lateral shoots. S -F leaves were measured on NF spurs that did not bloom, did not set fruit, or from which fruit abscised before June drop. S $+F$ leaves were measured on spurs carrying one to three fruit. The largest leaf on each spur was used for CER measurements. Only one leaf was measured per shoot or spur.

In 1989, CER was measured on 11 clear, sunny days between 1000 to $1200 \mathrm{HR}$; the 1989 measurements were first taken on 27 June (33 days after full bloom) and the last measurements on 24 Oct., $\approx 3$ weeks after harvest (5 Oct.). Over the season, 440 individual measurements of CER were made, ranging from a low of 15 measurements on 10 Aug. to a high of 76 on 27 June. Environmental conditions during CER measurements during the 1989 sampling period were as follows: photosynthetic photon flux, 1000 to $2000 \mu \mathrm{mol} \cdot \mathrm{m}^{-2} \cdot \mathrm{s}^{-1}$; leaf temperature, $28 \pm 5 \mathrm{C}$; relative humidity, $55 \pm 10 \%$; ambient $\mathrm{CO}_{2}$ concentration, $330 \pm 10$ $\mu \mathrm{mol} \cdot \mathrm{mol}^{-1}$; and $\mathrm{CO}_{2}$ drawdown, $30 \mu \mathrm{mol} \cdot \mathrm{mol}^{-1}$ over 15 to $20 \mathrm{sec}$ during each measurement. In 1990, CER measurements started on 14 June (31 days after full bloom) and continued through terminal bud formation, harvest ( 7 Oct.), and until $\approx 30 \%$ leaf drop on 30 Oct. Over the season, 896 individual CER measurements were made, ranging from a low of 25 on 8 Aug. to a high of 60 each on 18 and 25 July. Environmental conditions during the 1990 season were as follows: photosynthetic photon flux density, 1000 to 2000 $\mu \mathrm{mol} \cdot \mathrm{m}^{-2} \cdot \mathrm{s}^{-1}$; leaf temperature, $26 \pm 5 \mathrm{C}$ (in October, $21 \pm 2 \mathrm{C}$ ); relative humidity, $50 \% \pm 10 \%$; and ambient $\mathrm{CO}_{2}$ concentration, $320 \pm 10 \mu \mathrm{mol} \cdot \mathrm{mol}^{-1}$. To minimize environmental effects during any one measurement date, complete blocks were measured in turn.

Leaves and fruit. On 5 Oct. 1989 and on 7 Oct. 1990, all fruit and every 10th leaf within each leaf category were harvested from tagged limbs. Leaves and fruit were counted and weighed, total leaf area was measured using an area meter (model LI-3000; LI-COR), and leaves and fruit were oven-dried at 80C to a constant weight. Fruit count, fresh weight (FW), and DW and leaf count, area, FW, and DW were normalized based on per square centimeter limb cross-sectional area (LCSA) before statistical analyses.

Wood. In December of each year, after all leaves had fallen, the sample limbs were removed by cutting them at the junction with the trunk. Each sample limb was divided into five sections by cutting them at the rings of bud-scale scars separating each age category as follows: a) current season's shoots; b) 2 years old; c) 3 years old; d) 4- years old; and e) $\geq 5$ years old. Spurs were collected separately. For each test limb, five 1-cm-wide cross-sectional disks were randomly taken from the limb sections in each age group, except current-season's shoots. One side of each cross-sectional disk was cut to a plane surface with a sliding microtome (model 860; American Optical, Buffalo, N.Y.) before being photographed. Slides were projected onto a $45^{\circ}$ mirror, which reflected the image to a digitizing tablet (GTCO Corp., Rockville, Md.) for estimating cross-sectional areas of the annual rings in the disk. The ratio of the area of older wood ( $\geq 2$ years old) to the total area inside the cambial layer of the disk allowed an estimate of the proportion of the total cross-sectional area representing the wood increment added in the most recent growing season. Differentiating limb sections $>5$ years old by bud scales proved difficult. In addition, differences in the annual increment in cross-sectional disks from throughout the $\geq 5$-year-old limb section were insignificant. All limb sections were dried at $80 \mathrm{C}$ to a constant weight.

Erf (1987) showed that the wood in all annual rings in a limb cross-section exhibited a single density, independent of cropping and environmental conditions. Calculating the proportion of limb cross-sectional area in any annual ring and the total wood dry weight of that limb section allowed estimation of the amount of dry matter deposited in each limb section that season. In 1990, the two most recent rings (1989 and 1990) were grouped together to create one incremental percentage value.

Roots. On 27 Nov. 1990, soil cores $\left(\right.$ area $\left.=95 \mathrm{~cm}^{2}\right) 60 \mathrm{~cm}$ deep (volume $=5700 \mathrm{~cm}^{3}$ ) were taken at locations $0.6 \mathrm{~m}$ from north, east, west, and south of the trunk (Atkinson, 1977; Atkinson and Wilson, 1980). Soil was washed off over a 0.5-mm screen. Root diameters were measured with an electronic digital caliper (Max-Cal, Micrometer Manufacturing, Japan) and roots were divided into two categories: $<1 \mathrm{~mm}$ and 1 to $5 \mathrm{~mm}$. Root sections $>5 \mathrm{~mm}$ in diameter were found in only a few cores and were not included in the analysis because of their infrequency. The total length of all roots in each size category contained in each soil core was measured, and DW was determined after roots had been ovendried to a constant weight at 80C. Additionally, three to five main roots were removed from the trunk at a soil depth of 20 to $30 \mathrm{~cm}$ to visually assess the two most recent years' annual wood increments in structural roots, using the techniques described above.

Statistics. Data for all experiments were analyzed using the Statistical Analysis System (SAS) program package (SAS Institute, Cary, N.C.) as a split-split-plot treatment arrangement based on different leaf types nested within limbs located within trees. The full model statement included the main plot ( $F$ vs. NF trees), 
subplot (G limb vs. NG limb, in 1989 only), and sub-subplot (SH leaves vs. S - F leaves vs. S + F leaves), along with their interactions. Gas-exchange data were analyzed for each sampling date separately. Numbers of observations differed among and within dates due to environmental limitations. $G$ limbs with no crop behaved differently from all other treatments (Schechter et al., 1994). Adjusted means were calculated for the different treatment combinations ( $\mathrm{NF}-\mathrm{NG}, \mathrm{NF}-\mathrm{G}, \mathrm{F}-\mathrm{NG}$, and $\mathrm{F}-\mathrm{G}$ ), along with their associated standard errors.

\section{Results}

\section{Gas exchange}

$N F$ vs. $F$ trees, $N G$ limbs. No consistent $F$ effect on CER was observed at any time during the two seasons for either $\mathrm{SH}$ or $\mathrm{S}-\mathrm{F}$ leaves (Fig. 1). On F trees, S + F leaf CER was the lowest from mid-July on, in spite of the very high crop load on $F$ trees. Generally, SH leaf CER was higher than for S - F leaves, and S + F leaf CER (on F trees) was the lowest. Initial CER values in 1989 were relatively high (Avery, 1977) and decreased as the season progressed. In 1990, CER values were not as high as in 1989 and the decrease in CER was slower over the season. An unexplained temporary depression in CER was observed in August each year.

$F$ trees, $N G$ vs. $G$ limbs. Small $(8 \%$ to $10 \%)$ but consistent decreases in CER were found in $\mathrm{SH}$ and $\mathrm{S}+\mathrm{F}$ leaves on $\mathrm{G}$ limbs compared to those on NG limbs. These differences were not always statistically significant, but, when pooled across the entire season, were significant (data not presented). $S-F$ leaves on $G$ and NG limbs did not differ in CER on most dates during the season.

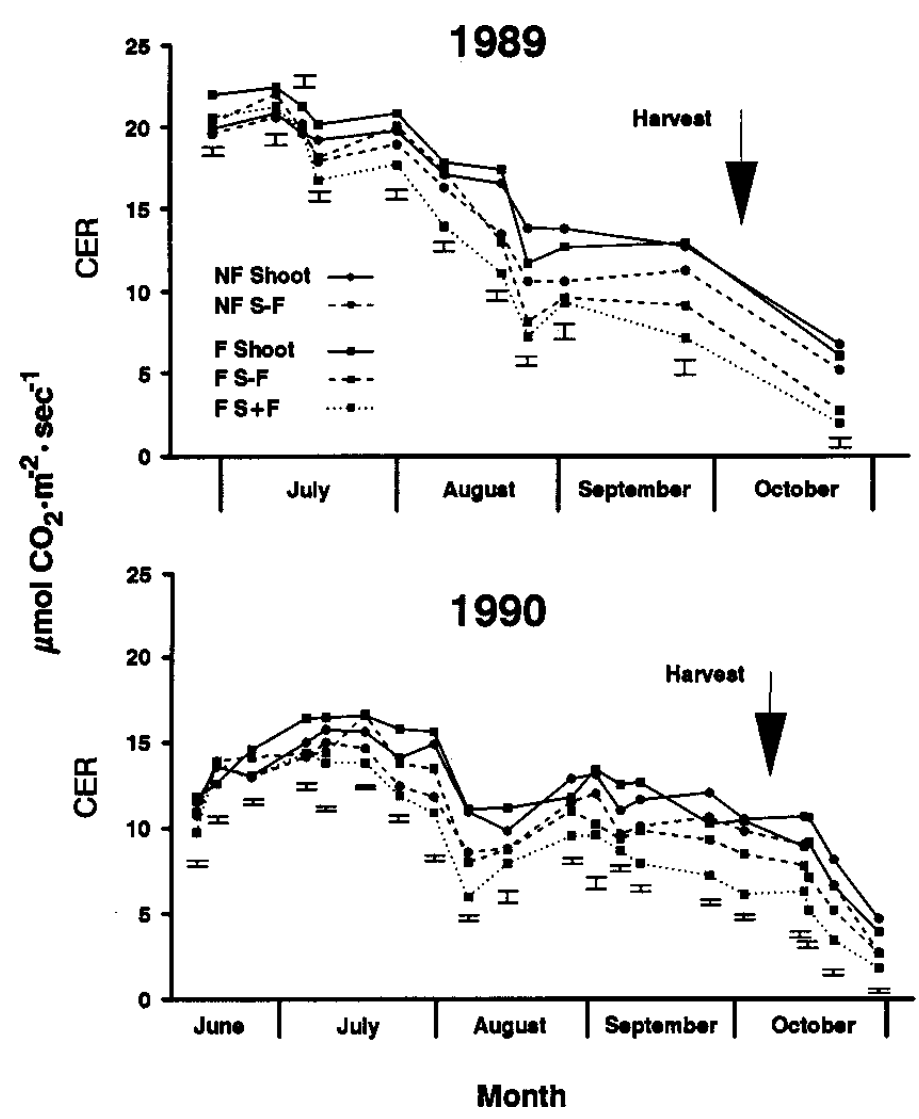

Fig. 1. Seasonal net $\mathrm{C}$ exchange rate (CER) of three apple leaf types: shoot leaves, leaves on spurs without fruit $(S-F)$, and leaves on spurs with fruit $(S+F)$, on fruiting (F) or nonfruiting (NF) trees in 1989 and in 1990. Vertical bars represent the largest SE among the five means for each date $(P \leq 0.05)$.
The CER values for different leaf types behaved similarly on both $\mathrm{NG}$ and $\mathrm{G}$ limbs ( $\mathrm{SH}>\mathrm{S}-\mathrm{F}>\mathrm{S}+\mathrm{F})$.

$N F$ trees, $N G$ vs. $G$ limbs. CER was reduced by $\approx 70 \% 11$ days after limbs were girdled (Fig. 2). By the beginning of August, CER was $\approx 1$ to $2 \mu \mathrm{mol} \mathrm{CO} / \mathrm{m}^{2}$ per sec. At the last measurement on 24 Oct., CER was around the $\mathrm{CO}_{2}$ compensation point in $\mathrm{SH}$ and $\mathrm{S}-$ F leaves. SC values for leaves on $\mathrm{G}$ limbs were very low (0.1 to 0.2 $\mu \mathrm{mol} \cdot \mathrm{m}^{-2} \cdot \mathrm{s}^{-1}$ ), while $\mathrm{C}_{\mathrm{i}}$ levels were high (Fig. 2B). Starch grains had accumulated in leaves on $\mathrm{G}$ limbs (Schechter et al., 1994).

\section{Leaves and fruit}

1989. Shoot leaf count and LCSA were about twice as large in NF trees as F trees (Table 1). Shoot leaf DW was higher in NF trees, and in NF-G limbs it was about three times that of F-NG limbs. The NF-G SH leaves also had the highest specific leaf area (DW/ LCSA), while the remaining leaves did not differ. Mean SH leaf area and DW were similar for all treatments except NF-G leaves, which had a higher mean SH leaf DW and area. Mean S-FleafDW was the highest for leaves on NF-G limbs, lowest for leaves on FNG limbs, and intermediate for leaves on NF-NG and F-G limbs. Leaves on F spurs were similar for $\mathrm{G}$ and $\mathrm{NG}$ trees. The total leaf count per LCSA was similar for all treatments, while leaf area and DW were higher in NF trees (Table 1). On NF trees, leaf area was divided more or less equally between $\mathrm{SH}$ and $\mathrm{S}-\mathrm{F}$ leaves, while F trees had about one-third of each leaf type. Fruit count per LCSA
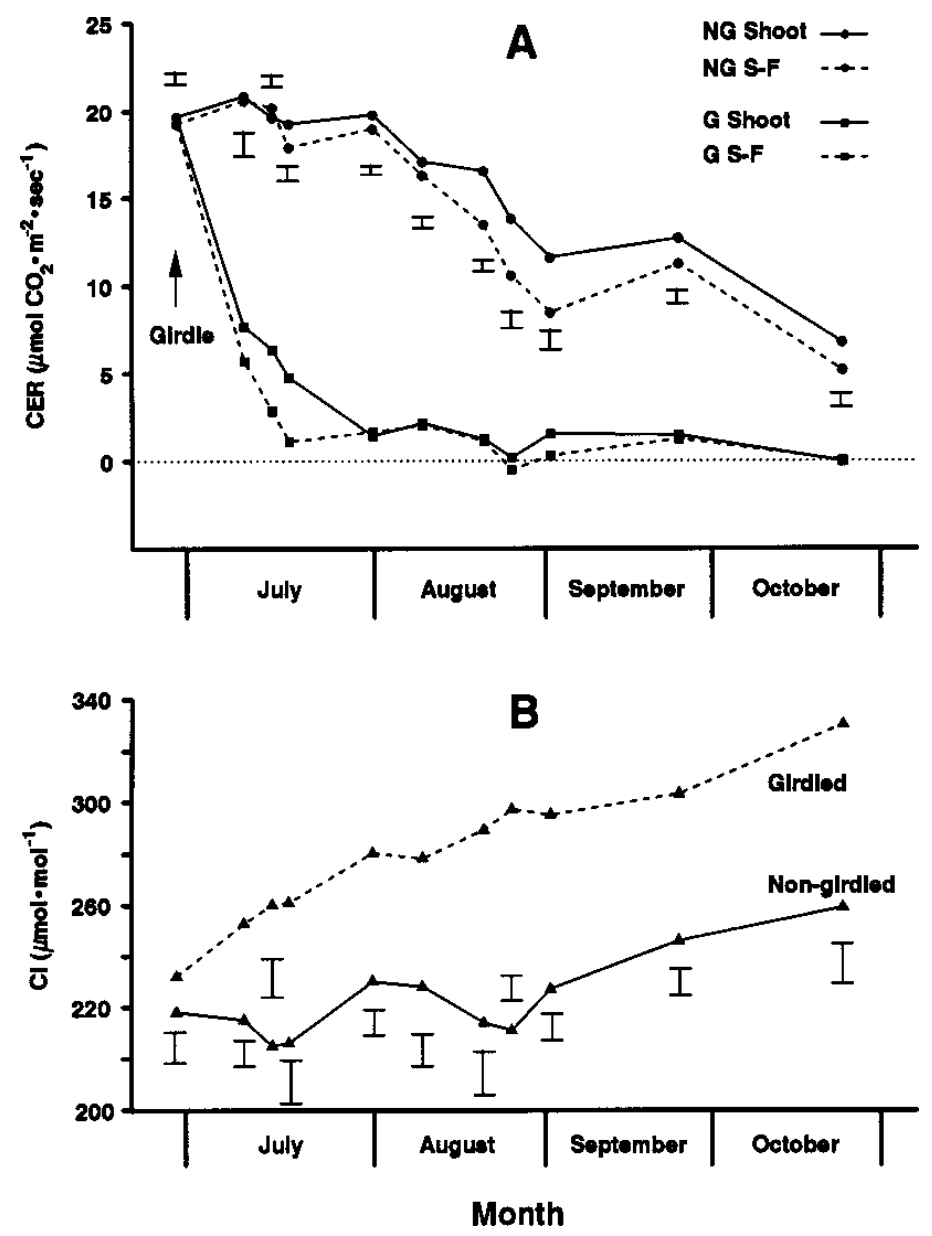

Fig. 2. Seasonal net C exchange rate (CER) on three apple leaf types: shoot leaves and leaves on spurs without fruit $(\mathrm{S}-\mathrm{F})$ on nonfruiting trees in 1989. (A) CER for leaves on girdled $(\mathrm{G})$ and nongirdled $(\mathrm{NG})$ limbs and $(\mathbf{B})$ leaf internal $\mathrm{CO}_{2}$ level $\left(\mathrm{C}_{\mathrm{i}}\right)$. Vertical bars represent the largest SE among the four means for each date $(P \leq 0.05)$. 
was similar for NG and G limbs, but total fruit weight (FW and DW) per LCSA was higher on G limbs and fruit were larger in diameter. Dry-matter concentration was higher in fruit from $G$ than NG limbs.

1990. There were more SH leaves per LCSA and they were larger on NF trees than on F trees (Table 2). SH leaf DW per LCSA did not differ between $\mathrm{F}$ and NF trees, but the specific leaf area was higher for NF SH leaves. No differences were found between $\mathrm{S}$ $\mathrm{F}$ leaf characteristics on $\mathrm{F}$ and NF trees. Leaves on $\mathrm{F}$ spurs were smaller and contained less DW than $\mathrm{S}-\mathrm{F}$ leaves. Total leaf area for $\mathrm{S}-\mathrm{F}$ leaves was $\approx 1.5$ times that for $\mathrm{SH}$ leaves on NF trees. $\mathrm{F}$ trees had about twice as much of their foliage area in $\mathrm{S}-\mathrm{F}$ than in $\mathrm{SH}$ or $\mathrm{S}+\mathrm{F}$ leaves.

Wood. The procedure used to estimate wood DW accumulation was reliable, consistent, repeatable, and had a low coefficient of variation. The NF-NG limbs had the largest proportion of LCSA and DW accumulation in newly formed wood in all limb age categories (Fig. 3, Tables 3 and 4). Two-year-old limb sections had $85 \%$ of LCSA as new increment, 3-year-old sections had $61 \%$, 4-year-old sections had $49 \%$, and limb sections $>4$ years old had $37 \%$. The lowest percentages of LCSA in new wood deposition were always found in F-NG limbs (58\%, 39\%, 28\%, 23\%, for 2-, 3, 4-year, and older limb age sections, respectively). G limbs on NF and $F$ trees had intermediate values. F reduced DW accumulation in current-season's shoot growth to a greater extent than in other

Table 1. Effect of fruiting (F) or nonfruiting (NF) and girdled (G) or nongirdled (NG) on apple shoot (SH) leaves, leaves on NF spurs ( $\mathrm{S}-\mathrm{F})$, and leaves on F spurs (S + F); leaf count, area, and dry weight (DW) per square centimeter cross-sectional area (LCSA), for all leaves count, area, DW/LCSA; and on leaf area distribution and fruit characteristics in 1989.

\begin{tabular}{|c|c|c|c|c|}
\hline \multirow{2}{*}{$\begin{array}{l}\text { Attribute }^{z} \\
\text { per LCSA }\end{array}$} & \multicolumn{2}{|c|}{ NF tree } & \multicolumn{2}{|c|}{ F tree } \\
\hline & NG & G & NG & G \\
\hline \multicolumn{5}{|l|}{ SH leaves $^{y}$} \\
\hline Count/LCSA (no./ $\left./ \mathrm{cm}^{2}\right)$ & $19.5 \mathrm{a}$ & $21.8 \mathrm{a}$ & $10.6 \mathrm{~b}$ & $11.7 \mathrm{~b}$ \\
\hline Area/LCSA $\left(\mathrm{cm}^{2} \cdot \mathrm{cm}^{-2}\right)$ & $516 \mathrm{a}$ & $628 \mathrm{a}$ & $283 \mathrm{~b}$ & $308 \mathrm{~b}$ \\
\hline DW/LCSA $\left(\mathrm{g} \cdot \mathrm{cm}^{-2}\right)$ & $5.6 \mathrm{~b}$ & $10.4 \mathrm{a}$ & $3.1 \mathrm{c}$ & $3.6 \mathrm{c}$ \\
\hline \multicolumn{5}{|l|}{$\mathrm{S}-\mathrm{F}$ leaves } \\
\hline Count/LCSA (no./cm²) & $40.3 \mathrm{a}$ & $33.4 \mathrm{a}$ & $21.1 \mathrm{~b}$ & $19.4 \mathrm{~b}$ \\
\hline Area/LCSA $\left(\mathrm{cm}^{2} \cdot \mathrm{cm}^{-2}\right)$ & $613 \mathrm{a}$ & $629 a$ & $259 \mathrm{~b}$ & $270 \mathrm{~b}$ \\
\hline DW/LCSA $\left(\mathrm{g} \cdot \mathrm{cm}^{-2}\right)$ & $5.8 \mathrm{~b}$ & $8.4 \mathrm{a}$ & $2.4 \mathrm{c}$ & $2.6 \mathrm{c}$ \\
\hline \multicolumn{5}{|l|}{$\mathrm{S}+\mathrm{F}$ leaves $^{\mathrm{x}}$} \\
\hline Count/LCSA (no./cm²) & --- & --- & 28.7 & 31.3 \\
\hline Area/LCSA $\left(\mathrm{cm}^{2} \cdot \mathrm{cm}^{-2}\right)$ & --- & --- & 331 & 312 \\
\hline DW/LCSA $\left(\mathrm{g} \cdot \mathrm{cm}^{-2}\right)$ & --- & --- & 2.9 & 2.6 \\
\hline \multicolumn{5}{|l|}{ All leaves ${ }^{y}$} \\
\hline Count/LCSA (no./cm²) & $60.0 \mathrm{a}$ & $55.3 \mathrm{a}$ & $60.5 \mathrm{a}$ & $60.4 \mathrm{a}$ \\
\hline Area/LCSA $\left(\mathrm{cm}^{2} \cdot \mathrm{cm}^{-2}\right)$ & $1129 \mathrm{a}$ & $1257 \mathrm{a}$ & $874 \mathrm{~b}$ & $890 \mathrm{~b}$ \\
\hline DW/LCSA $\left(\mathrm{g} \cdot \mathrm{cm}^{-2}\right)$ & $11.3 \mathrm{~b}$ & $18.7 \mathrm{a}$ & $8.3 \mathrm{c}$ & $8.9 \mathrm{c}$ \\
\hline Area distribution & & & & \\
\hline$(\%, S H: S-F: S+F)$ & $46: 54: 0$ & 50:50:0 & $32: 30: 38$ & $35: 30: 35$ \\
\hline \multicolumn{5}{|l|}{ Fruit $^{\mathrm{x}}$} \\
\hline Count (no. $\left./ \mathrm{cm}^{2}\right)$ & --- & --- & 6.6 & 6.6 \\
\hline $\mathrm{FW}\left(\mathrm{g} \cdot \mathrm{cm}^{-2}\right)$ & --- & --- & $513.0^{* *}$ & 661.0 \\
\hline $\mathrm{DW}\left(\mathrm{g} \cdot \mathrm{cm}^{-2}\right)$ & --- & --- & $62.2^{* *}$ & 87.8 \\
\hline Diameter $(\mathrm{cm})$ & --- & --- & $5.4^{*}$ & 6.1 \\
\hline Fruit DMC (\%) & & & $12.2^{* * *}$ & 13.3 \\
\hline
\end{tabular}

${ }^{\mathrm{z}} \mathrm{FW}=$ fresh weight; DMC $=$ dry-matter concentration.

'Mean separation within rows by Duncan's multiple range test, $P \leq 0.05$.

${ }^{\mathrm{x}}$ Mean separation within rows for two means separated by analysis of variance.

${ }^{*}$,** Significant at $P \leq 0.05$ or 0.01 , respectively. limb sections. The $\geq 5$-year-old limb sections accumulated the largest dry-weight increment, much greater than in 1- to 4-year-old limb sections combined (Tables 3 and 4). Spurs in NF trees accumulated about twice as much DW as spurs on F trees (Table

Table 2. Effect of fruiting (F) on the number of shoot $(\mathrm{SH})$ leaves, leaves on nonfruiting (NF) spurs $(\mathrm{S}-\mathrm{F})$, and leaves on F spurs $(\mathrm{S}+\mathrm{F})$; area and dry weight (DW) per square centimeter limb cross-sectional area (LCSA); and apple characteristics in $1990 .^{\mathrm{z}}$

\begin{tabular}{|c|c|c|}
\hline Attribute $^{y}$ per LCSA & NF tree & F tree \\
\hline \multicolumn{3}{|l|}{ SH leaves } \\
\hline Count/LCSA $\left(\right.$ no. $\left./ \mathrm{cm}^{2}\right)$ & $16.6^{* *}$ & 9.9 \\
\hline Area/LCSA $\left(\mathrm{cm}^{2} \cdot \mathrm{cm}^{-2}\right)$ & $457^{* *}$ & 261 \\
\hline DW/LCSA $\left(\mathrm{g} \cdot \mathrm{cm}^{-2}\right)$ & 4.6 & 3.1 \\
\hline \multicolumn{3}{|l|}{$\mathrm{S}-\mathrm{F}$ leaves } \\
\hline Count/LCSA (no./ $\left.\mathrm{cm}^{2}\right)$ & 53.5 & 45.0 \\
\hline Area/LCSA $\left(\mathrm{cm}^{2} \cdot \mathrm{cm}^{-2}\right)$ & 751 & 565 \\
\hline DW/LCSA $\left(\mathrm{g} \cdot \mathrm{cm}^{-2}\right)$ & 7.3 & 5.6 \\
\hline \multicolumn{3}{|l|}{$\mathrm{S}+\mathrm{F}$ leaves } \\
\hline Count/LCSA (no./ $\left./ \mathrm{cm}^{2}\right)$ & & 25.5 \\
\hline Area/LCSA $\left(\mathrm{cm}^{2} \cdot \mathrm{cm}^{-2}\right)$ & & 215 \\
\hline $\mathrm{DW}\left(\mathrm{g} \cdot \mathrm{cm}^{-2}\right)$ & & 1.9 \\
\hline \multicolumn{3}{|l|}{ All leaves } \\
\hline Count/LCSA $\left(\right.$ no. $\left./ \mathrm{cm}^{2}\right)$ & 70.1 & 80.5 \\
\hline Area/LCSA $\left(\mathrm{cm}^{2} \cdot \mathrm{cm}^{-2}\right)$ & 1209 & 1042 \\
\hline $\mathrm{DW}\left(\mathrm{g} \cdot \mathrm{cm}^{2}\right)$ & 11.9 & 10.6 \\
\hline \multicolumn{3}{|l|}{ Area distribution } \\
\hline$(\%, \mathrm{SH}: \mathrm{S}-\mathrm{F}: \mathrm{S}+\mathrm{F})$ & $38: 62: 0$ & $25: 54: 21$ \\
\hline \multicolumn{3}{|l|}{ Fruit } \\
\hline Count (no./ $\left./ \mathrm{cm}^{2}\right)$ & & 4.3 \\
\hline $\mathrm{FW}\left(\mathrm{g} \cdot \mathrm{cm}^{-2}\right)$ & & 575 \\
\hline $\mathrm{DW}\left(\mathrm{g} \cdot \mathrm{cm}^{-2}\right)$ & & 72.4 \\
\hline Diameter (cm) & & 6.5 \\
\hline Fruit DMC (\%) & & 12.6 \\
\hline
\end{tabular}

${ }^{\mathrm{z}}$ Mean separation between pairs by analysis of variance.

${ }^{y} \mathrm{FW}=$ fresh weight; DMC $=$ dry-matter concentration.

${ }^{* *}$ Significant at $P \leq 0.01$.

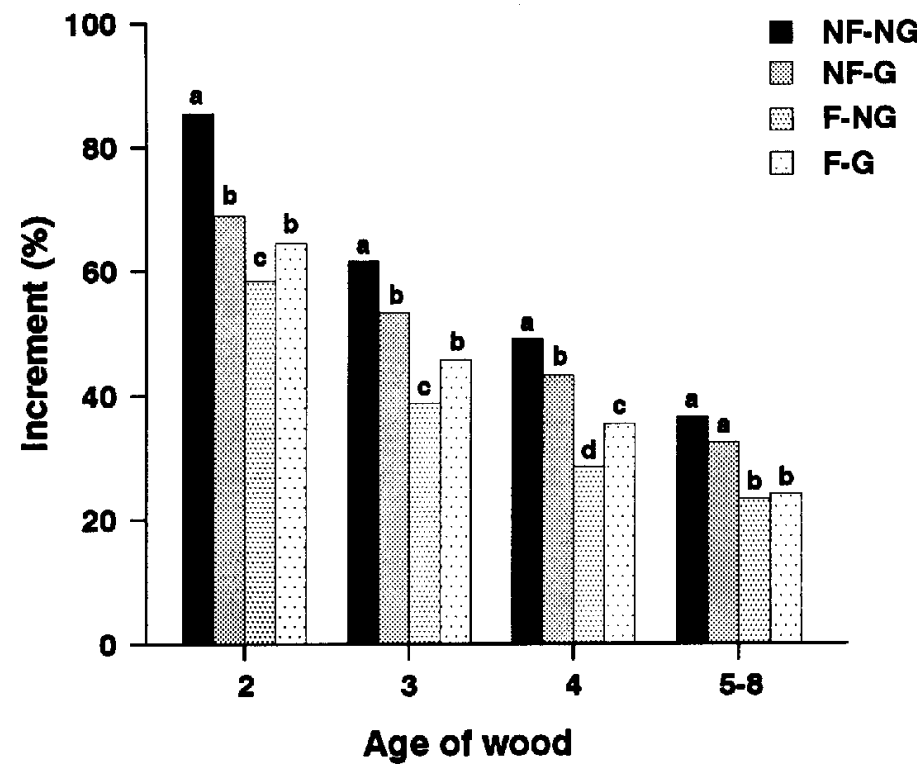

Fig. 3. The effect of fruiting $(\mathrm{F}=$ fruiting; $\mathrm{NF}=$ nonfruiting) and girdling $(\mathrm{G}=$ girdled; $\mathrm{NG}=$ nongirdled) on the percentage of apple limb cross-sectional area represented by the wood increment in 1989. Mean separation using Duncan's multiple range test $(P \leq 0.05)$. 
Table 3. The effect of fruiting and girdling on apple wood dry weight (DW) accumulation in limb sections of various ages and on spurs per square centimeter limb cross-sectional area (LCSA) in 1989.

\begin{tabular}{lccccc}
\hline \hline \multirow{2}{*}{ Limb } & \multicolumn{3}{c}{ Wood DW accumulation $\left(\mathrm{g} \cdot \mathrm{cm}^{-2} \mathrm{LCSA}\right)$} \\
\cline { 2 - 3 } \cline { 5 - 6 } section & \multicolumn{2}{c}{ Nonfruiting } & & \multicolumn{2}{c}{ Fruiting } \\
\cline { 2 - 3 } \cline { 5 - 6 } age & Nongirdled & Girdled & & Nongirdled & Girdled \\
\hline 1 & {$[\mathrm{~g}(\%)]$} & {$[\mathrm{g}(\%)]$} & & {$[\mathrm{g}(\%)]$} & {$[\mathrm{g}(\%)]$} \\
2 & $1.6(14)^{\mathrm{Z}}$ & $3.1(11)$ & & $1.0(6)$ & $1.7(9)$ \\
3 & $1.3(4)$ & $1.3(5)$ & & $0.7(4)$ & $0.7(4)$ \\
4 & $2.5(7)$ & $2.0(7)$ & & $0.9(6)$ & $1.1(6)$ \\
5 to 8 & $22.9(67)$ & $18.7(68)$ & & $11.8(75)$ & $13.7(71)$ \\
Spurs & $1.0(3)$ & $1.1(4)$ & & $0.5(3)$ & $0.6(3)$ \\
Total & $34.1(100)$ & $27.5(100)$ & $15.8(100)$ & $19.1(100)$
\end{tabular}

${ }^{\mathrm{z}}$ Mean separations by $t$ test $(P \leq 0.05)$. Means always differed between fruiting and nonfruiting. Means were always similar for girdled and nongirdled limbs, excluding 1-year-old wood, which differed for all treatments. Percentages within columns represent the proportional contribution of wood increment in each age category to the total accumulated wood LCSA for that treatment.

Table 4. The effect of fruiting on apple wood dry weight (DW) accumulation in 1989 and 1990 together per square centimeter limb crosssectional area (LCSA).

\begin{tabular}{lcc}
\hline \hline \multirow{2}{*}{$\begin{array}{l}\text { Limb } \\
\text { section }\end{array}$} & \multicolumn{2}{c}{ Wood DW $\left(\mathrm{g} \cdot \mathrm{cm}^{-2}\right.$ LCSA) } \\
\cline { 2 - 3 } age (years) & Nonfruiting & Fruiting \\
\hline $1(1990)$ & {$[\mathrm{g}(\%)]$} & $0.8(3)]$ \\
$2(1989+1990)$ & $3.3(6)^{\mathrm{z}}$ & $2.0(7)$ \\
3 & $4.4(9)$ & $0.9(3)$ \\
4 & $2.2(4)$ & $1.2(4)$ \\
5 to 8 & $3.1(6)$ & $22.9(80)$ \\
Spurs & $35.6(71)$ & $0.8(3)$ \\
Total & $1.8(4)$ & $28.6(100)$ \\
& $50.4(100)$ &
\end{tabular}

${ }^{\mathrm{z}}$ Mean separations by $t$ test $(P \leq 0.05)$. Means always differed between fruiting and nonfruiting. Percentages within columns represent the proportional contribution of wood increment in each age category to the total accumulated wood LCSA for that treatment.

$3)$. With the exception of the vigorous new shoot growth on NF trees, the proportional distribution of dry matter in $\mathrm{F}$ and $\mathrm{NF}$ limb sections was similar. Total DW incorporated into wood during the 1989 and 1990 seasons together was about twice as much in NF as in $\mathrm{F}$ trees (Table 4).

\section{Total DW accumulation}

The difference in the total dry matter per LCSA accumulated in $G$ vs. NGF limbs was assumed to represent the dry matter exported from NG limbs (Fig. 4). For F trees, $\approx 30 \mathrm{~g} \mathrm{DW} / \mathrm{LCSA}(\approx 34 \%$ of the total dry matter produced by NG limbs) was exported to other parts of the tree, while $66 \%$ of the total accumulated dry matter was used by sinks within the limb itself in the following proportions: fruit (72\%), structural wood (19\%), and foliage (9\%). In NF trees, the total DW accumulated in G and NG limbs was similar. More DW was accumulated in leaves on $G$ limbs, likely due in part to the formation of starch in the leaf tissues, while the low CER of those leaves contributed to the reduction in DW incorporated into the woody tissues.

\section{Roots}

In this study, NF trees had twice the DW per cubic centimeter

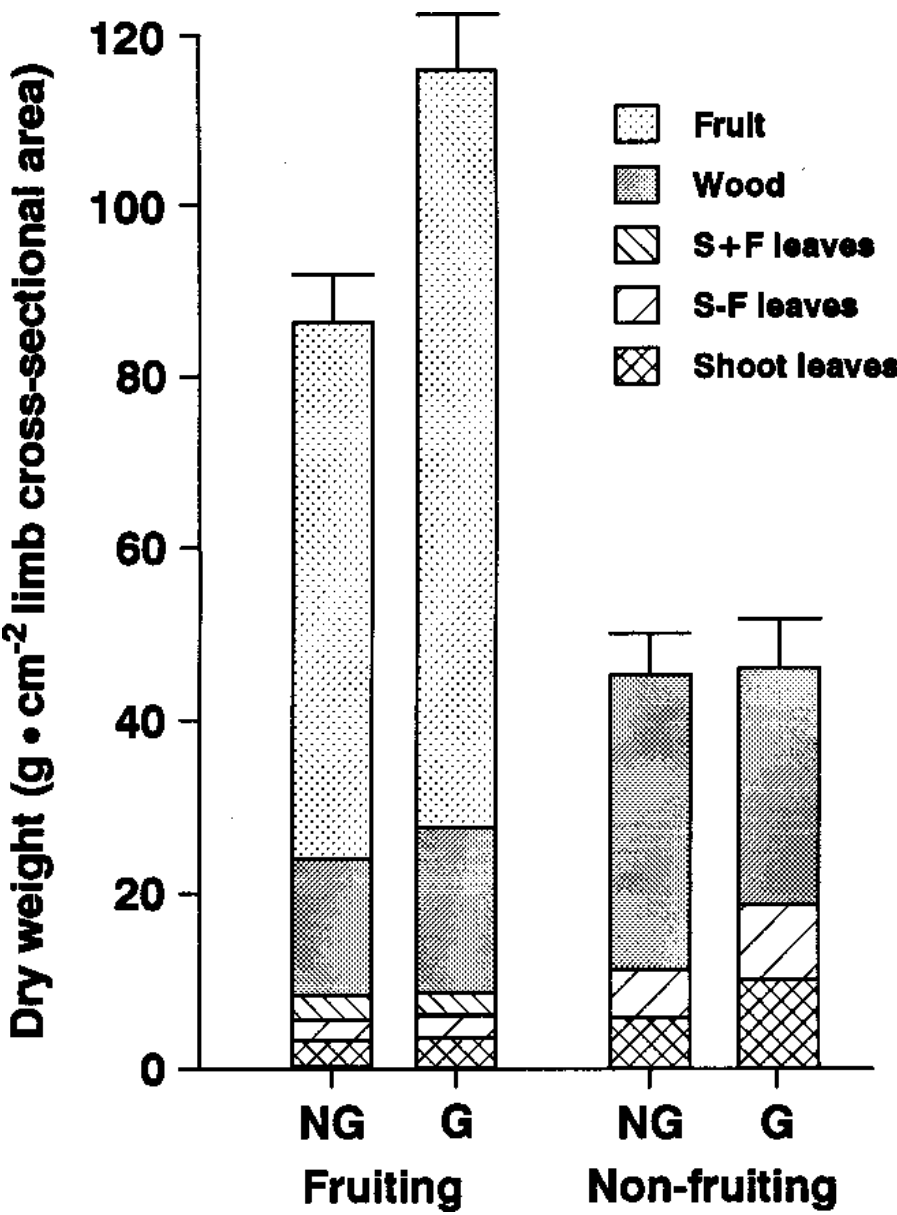

Fig. 4. The effect of fruiting ( $\mathrm{F}=$ fruiting; $\mathrm{NF}=$ nonfruiting $)$ and girdling $(\mathrm{G}=$ girdled; $\mathrm{NG}=$ nongirdled) on total dry weight accumulation per square centimeter of apple limb cross-sectional area in 1989. Vertical bars represent the SE of the means.

Table 5. Apple root dry weight (DW) (0- to 1-mm and 1- to 5-mmdiameter categories) and total root length per cubic centimeter soil-core volume as affected by fruiting in 1990 .

\begin{tabular}{llcc}
\hline \hline & \multicolumn{2}{c}{ Root diam } & \\
\cline { 2 - 2 } Tree & $0-1 \mathrm{~mm}$ & & $\begin{array}{c}\text { Length } \\
\left(\mathrm{cm} \cdot \mathrm{cm}^{-3}\right)\end{array}$ \\
\cline { 2 - 2 } type & \multicolumn{2}{c}{$1-5 \mathrm{~mW}\left(\mathrm{~g} \cdot \mathrm{cm}^{-3}\right)$} & $0.16^{* *}$ \\
Nonfruiting & $0.13^{* *}$ & 0.13 & 0.06 \\
Fruiting & 0.06 & 0.13 & 0.06 \\
\hline
\end{tabular}

${ }^{\mathrm{z}}$ Mean separation within columns by $t$ test.

${ }^{* *}$ Significant at $P \leq 0.01$.

soil-core volume of roots $<1 \mathrm{~mm}$ as $\mathrm{F}$ trees (Table 5), but DW was similar in $\mathrm{F}$ and $\mathrm{NF}$ trees for roots 1 to $5 \mathrm{~mm}$ thick. The large differences in total root length per cubic centimeter soil-core volume were due primarily to the relative amounts of $1-\mathrm{mm}$ diameter roots, while the 1 - to $\geq 5$-mm-diameter roots contributed more to total root DW per cubic centimeter.

The 2-year cumulative effect of cropping was clearly visible in the annual rings in 8 - to 10 -year-old root segments. Two wide rings were observed for NF trees, while rings from $\mathrm{F}$ trees were narrow.

\section{Discussion}

Source-sink relationships are probably more complex in large 
woody perennials than in small annuals, which have been the main model for studying such relationships (Gifford and Evans, 1981; Herold, 1980). Activity of some sinks may be limited in trees grown in pots or in young trees carrying a small crop. Sources, rather than sinks, may be the principal limiting factor in $\mathrm{C}$ assimilation in vigorous, healthy, mature, field-grown trees with extensive root systems and many potential growing points. For example, Lenz (1986) reported that potted apple trees produced a total of 4 $\mathrm{kg}$ of accumulated dry matter $(2.9 \mathrm{~kg}$ of that total in fruit) in one growing season. In our study, heavily cropping trees in the orchard carried 1500 fruit per tree on average in the 1989 season, representing up to $23 \mathrm{~kg}$ of DW in fruit alone [six times more than in Lenz's (1986) potted trees], in addition to increments of wood in vegetative sinks. Despite the strong sink effect of fruit and the absence of external constraints on sink activity in these trees, there was no effect on CER associated with the presence of fruit. Lack of a detectable F effect on CER and the absence of starch accumulation in leaves on NF trees indicated that the translocation system of NF trees was capable of removing assimilates from photosynthetic sites to the same degree as in $\mathrm{F}$ trees in response to vegetative sinks alone. Other field studies have reported the absence of a fruit effect on CER in limbs or spurs (Ferree and Palmer, 1982; Palmer, 1986; Palmer et al., 1991; Roper et al., 1986; Williams, 1986).

Seasonal trends in CER were not influenced by cropping. CER in apple leaves is a function of anatomical and physiological characteristics and leaf age (Schechter et al., 1992). There were 30to 60-day differences in leaf age between $\mathrm{SH}$ and spur leaf development from the start of $\mathrm{SH}$ growth to terminal bud formation. Leaf age, along with environmental effects on leaf morphology, may have accounted for the significant CER differences between $\mathrm{SH}$ and spur leaves in all treatments. The presence of fruit did not accelerate CER in $\mathrm{S}+\mathrm{F}$ leaves; on the contrary, $\mathrm{S}-\mathrm{F}$ leaves usually had a higher CER, associated with their more favorable anatomical and physiological attributes (Schechter et al., 1992). These findings also agree with those of Schechter et al. (1991).

CER values during the season were inversely proportional to $\mathrm{SC}$ (data not presented), resulting in little change in $\mathrm{C}_{\mathrm{i}}$, as has been reported for citrus (Kriedemann, 1971), stone fruit (DeJong, 1986), and apple (Lakso, 1986). Leaf SC and $C_{i}$ exhibited no seasonal changes that could be correlated with the presence of fruit, in contrast to observations in other fruit species (DeJong, 1986; Forney and Breen, 1985; Schaffer et al., 1986, 1987).

CER measurements represented a nearly instantaneous event, and therefore may not have adequately reflected daily or seasonal CER. The presence of fruit may have a soft or passive influence on CER and can provide a reservoir of water whereby SC can be maintained in the afternoon. Alternatively, the difference in DW accumulation per unit leaf area may be unrelated to CER, rather to respiration. If leaves have a higher dark respiration rate than fruit or wood, then NF trees, which have large leaf areas, may have greater respiratory $\mathrm{C}$ loss during the diurnal period, especially during the dark phase.

F-G limbs exhibited an $8 \%$ to $10 \%$ reduction in CER, possibly a consequence of some form of feedback inhibition. However, when NF limbs were $G$, further reducing sink activity by eliminating assimilate export, CER decreased significantly within 2 weeks, while red venation, leaf blade discoloration, and visible starch grain formation appeared $\approx 3$ weeks after girdling. Starch accumulation may alter chloroplast structure and function (Schaffer et al. 1986), resulting in significantly reduced CER and increased $\mathrm{C}_{\mathrm{i}}$ due to reduced mesophyll assimilation capability (Sharkey, 1985). The evidence presented here suggests that any internal control system over CER in apple trees has only a very limited capacity to regulate CER.

\section{Literature Cited}

Atkinson, D. 1977. Some observation on the root growth of young apple trees and their uptake of nutrients when grown in herbicide strips in grassed orchards. Plant \& Soil 49:459-471.

Atkinson, D and S.A. Wilson. 1980. The growth and distribution of fruit tree roots: some consequences for nutrient uptake, p. 259-272. In: D. Atkinson, J.E. Jackson, R.O. Sharples, and W.M. Waller (eds.). The mineral nutrition of fruit trees. Butterworths, Borough Green, U.K.

Avery, D.J. 1969. Comparisons of fruiting and deblossomed maiden apple trees, and of non-fruiting trees on a dwarfing and an invigorating rootstock. New Phytol. 68:323-336.

Avery, D.J. 1970. Effects of fruiting on the growth of apple trees on four rootstock varieties. New Phytol. 69:19-30.

Avery, D.J. 1975. Reduction in growth increments by crop competition, p. 103-106. In: H.C. Pereira (ed.). Climate and the orchard. Commonwealth Agr. Bureau, Slough, U.K.

Avery, D.J. 1977. Maximum photosynthetic rate: A case study in apple. New Phytol. 78:55-63.

Avery, D.J., C.A. Priestley, and K.J. Treharne. 1979. Integration of assimilation and carbohydrate utilization in apple, p. 221-231. In: R. Marcelle, H. Clijsters, and M. Van Poucke (eds.). Proceedings of a conference on photosynthesis and plant development. W. Junk, The Hague.

Barlow, H.W.B. 1964. An interim report on a long-term experiment to assess the effect of cropping on apple tree growth. Annu. Rpt. E. Malling Res. Sta. 1963:84-93.

Barlow, H.W.B. 1966. The effect of cropping on the number and kind of shoots on four apple varieties. Annu. Rpt.E. Malling Res. Sta. 1965:120124.

Barlow, H.W.B. 1975. Effects of cropping on the growth of orchard trees, p. 98-102. In: H.C. Pereira (ed.). Climate in the orchard. Commonwealth Agr. Bureau, Slough, U.K.

Chandler, W.H. and A.J. Heinicke. 1926. The effect of fruiting on the growth of Oldenburg apple trees. Proc. Amer. Soc. Hort. Sci. 23:36-46.

Daie, J. 1985. Carbohydrate partitioning and metabolism in crops. Hort. Rev. 7:69-108.

DeJong, T.M. 1986. Fruit effects on photosynthesis in Prunus persica. Physiol. Plant. 66:149-153.

Erf, J.A. 1987. Cropping and environmental effects on incremental vegetative growth of apple. $\mathrm{PhD}$ thesis, Univ. of Guelph, Ontario.

Erf, J.A. and J.T.A. Proctor. 1987. Changes in apple leaf water status and vegetative growth as influenced by crop load. J. Amer. Soc. Hort. Sci. 112:617-620.

Ferree, D.C. and J.W. Palmer. 1982. Effect of spur defoliation and ringing during bloom on fruiting, fruit mineral level, and net photosynthesis of 'Golden Delicious' apple. J. Amer. Soc. Hort. Sci. 107:1182-1186.

Flore, J.A. and A.N. Lakso. 1989. Environmental and physiological regulation of photosynthesis in fruit crops. Hort. Rev. 11:111-157.

Forney, C.F. and P.J. Breen. 1985. Dry matter partitioning and assimilation in fruiting and deblossomed strawberry. J. Amer. Soc. Hort. Sci. 110:181-185.

Forshey, C.G. and D.C. Elfving. 1979. Branch samples for yield and fruit size comparison in apple. HortScience 14:143-144.

Forshey, C.G. and D.C. Elfving. 1989. The relationship between vegetative growth and fruiting in apple trees. Hort. Rev. 11:229-287.

Forshey, C.G. and C.A. Marmo. 1985. Pruning and deblossoming effects on shoot growth and leaf area of 'McIntosh' apple trees. J. Amer. Soc. Hort. Sci. 110:128-132.

Forshey, C.G., R.W. Weires, B.H. Stanley, and R.C. Seem. 1983. Dry weight partitioning of 'McIntosh' apple trees. J. Amer. Soc. Hort. Sci. 108:149-154.

Fujii, J.A. and R.A. Kennedy. 1985. Seasonal changes in the photosynthetic rate in apple trees. A comparison between fruiting and non-fruiting trees. Plant Physiol. 78:519-524.

Ghosh, S.P. 1973. Internal structure and photosynthetic activity of different leaves of apple. J. Hort. Sci. 48:1-9. 
Gifford, R.M. and L.T. Evans. 1981. Photosynthesis, carbon partitioning and yield. Annu. Rev. Plant Physiol. 32:485-509.

Hansen, P. 1970. ${ }^{14} \mathrm{C}$ studies on apple trees. VI. The influence of the fruit on the photosynthesis of the leaves, and the relative photosynthetic yields of fruit and leaves. Physiol. Plant. 23:805-810.

Hansen, P. 1971. The effects of cropping on uptake, contents, and distribution of nutrients in apple trees. Tidsskrift for Planteavl 75:615625.

Head, G.C. 1969. The effect of fruiting and defoliation on seasonal trends in new root production in apple trees. J. Hort. Sci. 44:175-181.

Herold, H. 1980. Regulation of photosynthesis by sink activity-The missing link. New Phytol. 86:131-144.

Kriedemann, P.E. 1971. Photosynthesis and transpiration as a function of gaseous diffusive resistances in orange leaves. Physiol. Plant. 24:218-225.

Lakso, A.N. 1986. Photosynthesis in fruit trees in relation to environmental factors, p. 6-13. In: A. Lakso and F. Lenz (eds.). The regulation of photosynthesis in fruit trees. New York State Agr. Expt. Sta., Geneva. Spec. Publ.

Lenz, F. 1986. Fruit effect on transpiration and dry matter production in apples, p. 101-104. In: A. Lakso and F. Lenz (eds.). The regulation of photosynthesis in fruit trees. New York State Agr. Expt. Sta., Geneva. Spec. Publ.

Maggs, D.H. 1963. The reduction in growth of apple trees brought about by fruiting. J. Hort. Sci. 38:119-128.

Monselise, S.P. and F. Lenz. 1980. Effect of fruit load on photosynthetic rates of budded apple trees. Gartenbauwissdraften 45:220-224.

Palmer, J.W. 1986. Seasonal variation of light saturated photosynthetic rate of 'Golden Delicious' apple leaves as influenced by leaf type and crop load, p. 30-33. In: A. Lakso and F. Lenz (eds.). The regulation of photosynthesis in fruit trees. New York State Agr. Expt. Sta., Geneva. Spec. Publ.

Palmer, J.W., Y.L. Cai, and Y.Edjamo. 1991.Effect of part-tree flowering thinning on fruiting, vegetative growth and leaf photosynthesis in 'Cox's Orange Pippin' apple. J. Hort. Sci. 66:319-325.

Priestley, C.A. 1970a. Some observations on the effect of cropping on the carbohydrate content in trunks of apple trees over a long period. Annu.
Rpt. E. Malling Res. Sta. 1970:121-123.

Priestley, C.A. 1970b. Carbohydrate storage and utilization, p. 113-127. In: L.C. Luckwill and C.V. Cutting (eds.). Physiology of tree crops. Academic Press, London.

Proctor, J.T.A., R.L. Watson, and J.J. Landsberg. 1976. The carbon budget of a young apple tree. J. Amer. Soc. Hort. Sci. 101:579-582.

Rom, C.R. and D.C. Ferree. 1986. Influence of fruit on spur leaf photosynthesis and transpiration of 'Golden Delicious' apple. HortScience 21:1026-1029.

Roper, T.R., J. Keller, W.H. Loescher, and C.R. Rom. 1986. Seasonal and diurnal changes in photosynthesis and nonstructural carbohydrates in sweet cherry, p. 24-29. In: T.M. DeJong (ed.). Regulation of photosynthesis in fruit crops. Univ. of California, Davis.

Schaffer, B., J.A. Barden, and J.M. Williams. 1986. Net photosynthesis, stomatal conductance, specific leaf weight and chlorophyll content of strawberry plants as influenced by fruiting. J. Amer. Soc. Hort. Sci. 111:82-86.

Schaffer, B., L. Ramos, and S.P. Lara. 1987. Effect of fruit removal on net gas exchange of avocado leaves. HortScience 22:925-927.

Schechter, I., D.C. Elfving, and J.T.A. Proctor. 1991. Apple tree canopy development and photosynthesis as affected by rootstock. Can. J. Bot. 69:295-300.

Schechter, I., D.C. Elfving, and J.T.A. Proctor. 1992. Morphological differences among apple leaf types. HortScience 27:101-103.

Schechter, I., J.T.A. Proctor, and D.C. Elfving. 1994. Apple fruit removal and limb girdling affect fruit and leaf characteristics. J. Amer. Soc. Hort. Sci. 119:157-162.

Sharkey, T.D. 1985. Photosynthesis in intact leaves on $\mathrm{C}_{3}$ plants: Physics, physiology and rate limitation. Bot. Rev. 51:53-105.

Verheij,E.W.M. 1972. Competition in apple as influenced by Alar sprays, fruiting, pruning and tree spacing. Meded. Landbouwhogeschool, Wageningen 72-4:1-54.

Williams, E.L. 1986. Net $\mathrm{CO}_{2}$ assimilation of Vitis Vinifera L. leaves as affected by alterations in source/sink relationships of the vine, p. 35-38. In: T.M. DeJong (ed.). Regulation of photosynthesis in fruit crops. Univ. of Calif., Davis. 